\title{
Gender and Academic Promotion to Full Professor in Ontario
}

\author{
Paul Millar \\ JANE E. BARKER
}

\begin{abstract}
This is a study of 933 academic promotions from associate to full professor in Ontario, Canada for the period 2010-2014. Publicly available sources provided a bibliometric profile including gender, year of promotion, university, academic discipline, salary, type and number of publications and number of authors for each promotion to full professor. We found a large gender gap in academic promotions favouring men, which is explained mainly by a structural focus on male-dominated academic disciplines. We also found large differences in numbers of publications by academic discipline, which was substantially reduced after considering the number of authors per publication. Business professors were paid substantially more than other professors at the time of promotion. Our study focused on publications, and given this limitation the results should be taken in the context that there are multiple considerations for promotion. Publication quality and impact, grants and patents, were not adjusted for.
\end{abstract}

Keywords: Gender; Academic Promotion; Salary

Résumé. Cette étude utilise 933 promotions académiques d'un professeur associé à un professeur titulaire en Ontario, Canada pendant la période 2010-2014. Les sources accessibles au public ont fourni un profil bibliométrique comprenant le sexe, l'année de promotion, l'université, la discipline universitaire, le salaire, le type et le nombre de publications et le nombre d'auteurs pour chaque promotion au rang de professeur titulaire. Nous avons constaté un écart considérable entre les sexes dans les promotions académiques en faveur des hommes, ce qui s'explique principalement par une focalisation structurelle sur les disciplines académiques dominées par les hommes. Nous avons également constaté de grandes différences dans le nombre de publications par discipline universitaire, qui a été considérablement réduit après prise en compte du nombre d'auteurs par publication. Les professeurs de commerce étaient mieux payés que les autres professeurs au moment de la promotion. Notre étude s'est concentrée sur les publications, sans égard à la qualité et l'impact des publications, subventions et brevets.

Mots clés: Genre; Promotion Académique; Salaire

(C) Canadian Journal of Sociology/Cahiers Canadiens de Sociologie 45(1) 2020 


\section{INTRODUCTION}

To date there has been limited research in Canada looking at the gender wage gap among academics. Those Canadian studies that have been done have used either data from a Statistics Canada survey or data consisting of salary information ("Sunshine" list) published by the Ontario government. For example, a study by the Canadian Association of University Teachers (CAUT) used data collected by Statistics Canada on academic salaries, controlling for age, rank, province and inflation (CAUT, 2011). The Statistics Canada University and College Academic Staff System survey is a census of Canadian academic faculty from $1970 / 1971$ to $2010 / 2011$. It is now discontinued (Statistics Canada, 2012). CAUT found a generally persistent pay gap favouring males, with female salaries ranging from 95 to $97 \%$ of males, depending on rank, in 2006.

In 2015, McMaster University announced that it was going to award all full-time female faculty members with an annual salary adjustment of $\$ 3,515$ as a result of an internal investigation of the gender wage gap that existed at McMaster in 2012 and 2013. The study examined McMaster faculty ( $\mathrm{N}=939$ in 2012, $\mathrm{N}=943$ in 2013) for gender differences using institutional data. They reported a gender difference in salary of $\$ 2,992$ in 2012 and $\$ 4,037$ in 2013, both in favour of male faculty, that was not accounted for by highest degree, rank, faculty, appointment stream, years in rank, and whether the faculty held a Canada Research Chair (a Canadian federal award that increases salary). The study did not adjust for measures of productivity (McMaster University Office of Institutional Research and Analysis, 2014). The amount $(\$ 3,515)$ that McMaster University paid to the female full-time faculty as a salary adjustment consisted of the average annual salary difference over that 2 year (2012 and 2013) period.

Warman, Woolley, \& Worswick (2010) used the Statistics Canada University and College Academic Staff System (UCASS) survey for the years 1970 to 2001 and found that a "gender earnings gap remains, the bulk of which can be explained by differences in men's and women's rank and field" (p.347). They further noted that there had been a decrease in the unexplained earnings gap over time. The 'unexplained' earnings gap declined from over $30 \%$ to less than $20 \%$ by 2001 . What is critical to note here is that in this quite recent study, a proportion of the wage gap remained unaccounted for. They did not study promotion, but controlled for discipline, rank, age, place of degree, type of degree, country of training and fixed effect of institution. Some data from this survey (UCASS) is publicly available through the CANSIM facility on the 
Statistics Canada website. From these data we were able to determine, for example, that $38 \%$ of associate professors in Ontario were female in the academic year 2010/2011 (the most recent year available), with a long-term upward trend (Statistics Canada, 2017).

A study of the changes in the University of Manitoba over a 10-year period found that although the gender disparity had decreased slightly, a significant income gap remained (Brown, Troutt, \& Prentice, 2011). They identified an overrepresentation of women at the lower ranks as a contributor to the wage gap. The authors suggested that in order to close the salary gap, monitoring of key factors that contribute to the gap would be necessary. Included among these factors are the number of women and men hired at the different ranks, rates of promotion, and starting salaries. Rates of promotion and unequal promotion rates for men and women were considered key variables for future monitoring.

An American survey of 28,576 academics conducted in 1999 controlled for productivity and found that the males earned $20.7 \%$ more than females, at least $17 \%$ of which could not be explained by a range of factors (i.e. was due to discrimination) (Barbezat \& Hughes, 2005).

\section{Productivity}

The previously mentioned Canadian studies on the gender wage gap and academia did not adjust for measures of academic productivity, such as publications. However, an early study of the gender differences in academic salaries in Canada (Ornstein \& Stewart, 1996) found that there was a gender gap in 1986 even after adjusting for productivity, although the authors estimated that this might be decreasing over time. A more recent study that examined the causes of academic productivity (i.e. not salaries) among academic economists used data published by the government of Ontario pursuant to the Public Sector Salary Disclosure Act, 1996 (the "Sunshine list") (Sen, Ariizumi, \& Desousa, 2014). This study found gender effects on the productivity of economics professors in Ontario after adjusting for a variety of factors; that is, males were more likely to publish in top-10 journals and to hold a SSHRC grant. However, this study could not state whether the greater productivity entirely explained salary disparities by gender. A study of the productivity of academics in the province of Quebec found that, after age 38, female professors were less productive than their male counterparts although salary was not considered in this study (Larivière, Vignola-Gagné, Villeneuve, Gélinas, \& Gingras, 2011). Another study, of 5,217 Canadian professors surveyed in 1987, also found that men 
publish more than women (Nakhaie, 2002). However, it also found that "rank, years since $\mathrm{PhD}$, type of university, discipline and department, amount of research time and marital status are better associated with publication than gender" (p. 172) and that "gender differences disappear when the focus is on the last three years of publication" (p. 172). Hence while productivity is an important consideration when accounting for salary disparity, it may not entirely explain such differences.

These studies of Canadian academics suggest that women are at a disadvantage in terms of salary and that this disadvantage cannot be explained by the most common measure of academic achievement, that of publishing productivity.

Although many of the above studies found academic productivity could not explain gender gaps in the academy, some studies do find a productivity gap. For example, in their review of the literature, Bentley and Adamson (2003) noted "women in academic careers are disadvantaged compared with men in similar careers. Women faculty earn less, are promoted less frequently to senior academic ranks, and publish less frequently than their male counterparts" (p.1). In 1984, Cole and Zuckerman referred to the phenomenon of male academics out-publishing their female counterparts as the "productivity puzzle". They noted that since 1920, "more than 50 studies of scientists in various fields show that women publish less than men" (Cole \&Zuckerman, 1984, p. 217). In the years since Cole and Zuckerman coined the term, the puzzle has yet to be fully explained (Bentley \& Adamson, 2003), even though gender differences in productivity among academics continue to be explored. Mauleón, Bordons, and Oppenheim (2008) offered an explanation of this puzzle involving career stage. They found that, among those scientists in Biology and Bio-medicine who were relatively new to institutions in Spain (less than 10 years), women were more productive than their male counterparts. However, for those who were at their institution for between 11 and 20 years, or 21 and 30 years, the women had lower productivity than did the men (Mauleón et al., 2008). Other research has not found differences in productivity among those at the same rank. Examination of productivity among male and female researchers in the sciences (Chemistry and Natural Resources) in Spain did not find any significant gender differences among those at the same ranks (Bordons, Morillo, Fernández, \& Gómez, 2003). A study of 852 social scientists in the Netherlands found that there were gendered differences in performance as measured by publication records for the sample as a whole. However, when the publication records for the younger generation of researchers were examined, the gender differences in productivity disappeared (van Arensbergen, van der Weijden, \& van 
den Besselaar, 2012). More recent studies have focused on attempting to better understand the gender difference in productivity among scholars at all ranks. For example, in a sample of 1,699 social work doctoral faculty in the United States, women at all ranks were assessed as being less productive (as measured by H-Index scores) than were males (Carter, Smith, \& Osteem, 2017). So, while gendered differences in productivity have been observed, this pattern might be changing with younger scholars (Bordons et al., 2003; Mauleón et al., 2008; van Arensbergen et al., 2012).

In an examination of gender and productivity in Croatia, Prpić (2002) found a gendered disparity, with men out-publishing women. She reported that the most important factor influencing women's productivity was their position within the organization. When individual productivity factors were explored, international contacts was identified as the best predictor of productivity for females. For males it was attendance at scientific conferences and reviewing colleagues' papers (Prpić, 2002). In a somewhat related finding, Spanish female psychology professors produced fewer articles in 2007 and were less likely to be involved in collaborations that were international than were the men studied (Barrios, Villarroya, \& Borrego, 2013).

An early study of gender differences in the productivity of biochemistry professors found that women published less than men however the number of citations per article was not different. The higher productivity of men was due to the over-representation of women who did not publish (at all) and under-representation of very high producers (Long, 1992). Another model examining gender differences in productivity found that while there were significant asymmetries in the US in 1969 and 1973, these inequalities became insignificant by 1993 when the model adjusted for "personal characteristics, structural positions, and marital status" (Xie \& Shauman, 1998). A more recent study however found that variation in publications between men and women were evident in 2004, with some of the difference related to the presence of children (Hunter \& Leahey, 2010). There was a greater negative effect of having children on academic productivity for women than for men.

\section{Gender Wage GaP}

As was noted earlier, Bentley and Adamson's (2003) review of the literature found evidence that women in academia earn less than their male counterparts. In a study of 262 economics university professors in 
the UK, Blackaby, Booth and Frank (2005) found that male professors were paid more after adjusting for a wide range of factors including productivity (publications), teaching scores and grants. This gap was true for both promotions and within-rank salaries. Outside offers were found to explain some of the gender gap in salary, that is, men applied more aggressively to other institutions and were able to leverage outside offers into greater salary gains.

In a comparison of gender wage disparity over time, a study of American university professors found that the gender wage disparity among academics remained substantial despite the increasing number of female academics (Benjamin, 1999). This disparity was greater in 1998 than in 1975, but due in part to the larger proportions of women joining the professoriate at entry levels. However, this did not completely explain the growth in the gap which was also attributed in part to delays in promotion and did not control for productivity.

\section{Patterns by Discipline}

There is evidence of pronounced differences in publication patterns by academic discipline. For example Kyvik (2003) reported that academics in Humanities and Social Sciences published fewer journal articles but a much greater proportion of their publications as books than did other disciplines, such as those in the Natural Sciences, Medicine, or Technology. Similarly, Jung (2012) found a similar difference between these two categories for Hong Kong academics, however, the difference in book publishing was not as great in this sample. A study of Korean academics found similar differences in publications, but found that for the Social Sciences institutional factors such as collegiality and a focus on productivity played a role in increased productivity which were not found in other disciples. The only exception to this was that in Engineering, collegiality negatively affected productivity (Shin \& Cummings, 2010). One difference may be that business faculty receive greater compensation (Brown, 2012; Dulek \& Fielden, 1992). Despite this, a study - with an admittedly small sample size - found that these faculty believed they were undercompensated and underappreciated (Comm \& Mathaisel, 2003). Hence, it is expected that a study involving academic productivity will be likely to find significant differences by discipline and possibly higher wages for business faculty. 


\section{Current Study}

The current investigation explored the role of gender in the promotion of academics to full professor. Women have been employed as academics for many decades yet it is clear that they continue to be paid less than their male counterparts. One of the mechanisms for this disadvantage may be related to the role of promotion. That is, women may wait longer for promotion (perhaps due to career interruption as result of maternity leaves) or may be denied promotion (as a result of discrimination) when men with the equivalent record of achievement are promoted. Promotion to full professor is the highest academic rank achievable and a key point of salary differentiation. While the number of publications and their type is critical to the promotion process, and has been used as a measure of production in numerous studies (Bordons et al., 2003; Cole \& Zuckerman, 1984; Mauleón et al., 2008; Prpić, 2002), it is not the only, or even necessarily the determinative, attribute. Committees that review promotions use many other attributes such as publication quality and impact, grants and patents. While this study does not adjust for all of the criteria, it accounts for number of publications and publication type in order to see if the promotion process is more stringent for women than for men.

\section{Data and Methods}

Data for this project were gathered from two main sources. The first is a list published by the government of Ontario pursuant to the Public Sector Salary Disclosure Act, 1996 (the "Sunshine list"). This contains the first and last names, position, salary and taxable benefits for all government employees, including university professors, in Ontario earning at least $\$ 100,000$ for each calendar year since 1996. Currently, virtually all full professors in Ontario earn more than this threshold. In two reports on academic salaries for the 2008/2009 and 2010/2011 academic years (just before and after the start of the period under study) Statistics Canada (Statistics Canada, 2009, 2012) reported the bottom $10^{\text {th }}$ percentile of salaries of full professors ${ }^{1}$ by university in Ontario (See Table 1). Although some salary scales provide for full professor salaries under $\$ 100,000$, in practice this threshold excludes few at the rank of full professor. The sunshine list is published on the Ontario government web site each year in the spring, with an addendum following later in the year. For this analysis, the amount for taxable benefits is included with salary (total salary). The information in the position field was used to

1. Excludes professors in administrative roles. 
determine whether the person was an academic and, if so, her or his rank. Promotions were identified by examining the rank over time for a change from associate to full professor.

Some data correction was required to enable this procedure since, for example, names were sometimes entered slightly differently from year to year. Most universities provided enough information in the position field to make the determination of academic rank. Exceptions included Carleton University, which listed only "Faculty member" for the position of all faculty in all years, Wilfred Laurier University and the University of Toronto. The University of Ottawa listed all faculty simply as "Professor" regardless of rank in the years 2002-2009, however examining the rank in the years before and after this period allowed the assignation of rank in most cases for the period under study. We also limited our study to universities categorized by Maclean's magazine as Medical/Doctoral, Comprehensive or Primarily Undergraduate (see Table 2). Hence our sample includes all but three of these Ontario universities for the years 2010-2014. The data were copied from the Ontario government web site, pasted into an Excel spreadsheet, then processed using the Stata statistical package.

The second main source of information for our study was derived from publicly available sources on academics and their publications. This included university web sites, Google Scholar and personal web sites of academics. The university web site provided the department and the gender presentation of the academic. Gender presentation was assessed using the picture of the person and/or whether text referred to the person as "he or "she". No non-binary genders (or pronouns) were encountered. The departments were used in most cases to group the professors into disciplines according to the primary groupings of Statistics Canada Classification of Instruction Programs (CIP). The primary groupings were: Humanities, Education, Social Science (including Law), Business, Engineering (including Architecture), Mathematics and Computer Science, Health (including Medicine), Science, and Social Science. The ability to account for professional schools (Law, Architecture, Medicine and Education) was retained. Also, further grouping was made into STEM (Science, Technology/Computer Science, Engineering and Mathematics) disciplines.

No single source available is currently complete and accurate for publications in all disciplines; this includes proprietary sources such as Web of Science (published by Thomson-Reuters) and scopus.com (published by Elsevier). Microsoft also has a publicly available database of academic publications. This is also true of the three sources we used: university web sites, personal web sites of professors and Google 
Scholar. In order to construct a bibliometric profile for each individual identified as having been promoted to full professor, a total count of publications (where full credit is counted for each author) was used as an estimate of productivity. Using publication number as an approximation for productivity has been reported in the literature. Straight counts (counting only the first author) or fractional counts (where partial credit is assigned to 1 /number of authors) were not included (Bordons et al., 2003; Mauleón et al., 2008). The publication information was gathered manually from personal and university web sites of academics, and manually or semi-automatically from Google Scholar. The semiautomatic techniques to capture data from Google Scholar included: Google Scholar save to "My Library", the software program Zotero, spreadsheets that processed Google Scholar Profiles, and a script written in the Python language. Publications had to be primary, peer-reviewed research and were categorized as a book, edited book, book chapter or peer-reviewed journal article. Conference papers and proceedings were recorded separately, given that in Engineering and Computer Science these are considered to be peer-reviewed publications. Secondary and non-peer-reviewed works such as reports, textbooks, book reviews and lecture notes were not included. Attributes recorded included the title, publication or publisher, year of publication, the number of authors, and the position of the academic in the list of authors. To be included in the number of publications, a publication had to be published by the year of promotion.

\section{Results}

We identified 933 promotions from associate to full professor in the period 2010-2014 (see Table 3). More than twice as many of these promotions were to men (641) than women (292).

This imbalance could not be explained by fewer female associate professors: as mentioned above associate professors in Ontario are at least $38 \%$ female. The largest contributors to this gender gap in promotions were Engineering, Science, and Mathematics/Computer Science, the so-called STEM disciplines, accounting for a total of about $70 \%$ of the gender gap in promotions (see Figure 1). The gender gap for promotions in social science was largely due to the areas of geography and environment where there were greater numbers of men promoted than women. This is further illustrated when looking at the numbers of promotions by gender and discipline (see Figure 2). From these charts it is evident that women's promotions were proportionally derived more 
from the humanities and health disciplines than men's, whereas men's promotions originated more from the STEM disciplines and business than did women's.

When examining gender differences in publications upon promotion to full professor, it was found that men published about $31 \%$ more journal articles and were paid more in the year of their promotion, while women published 57\% more books (see Table 4). With respect to salary, it should be noted that salaries in Ontario universities are highly structured by collective agreements negotiated by faculty associations. Given this context, the lower salaries for women in the year of promotion noted here could be the result of women being promoted earlier than men, although we could not test for this with the data in this study.

\section{Publications at Time of Promotion by Discipline}

Table 5 shows the distributions of publications by discipline. The discipline with the most journal articles upon promotion was health (including medicine), although if conference papers and proceedings were included, the STEM disciplines would have a similar number. The values for Fine Arts should be considered with caution because the number of promotions was small for this discipline and the distributions are skewed, with one or two professors responsible for most of the publications. Moreover, different criteria are often used for assessing promotion in fine arts, such as performances and exhibitions. Different publication patterns by discipline were observed, with Humanities publishing the greatest number of books and edited books on average (see Figure 3). Interestingly, there seems to be an ordinal relationship by discipline for the number of articles and books. That is, the more a discipline concentrates on articles, the fewer books it publishes and vice versa.

One discipline stands out with respect to salary. Business professors were, on average, paid about a third more than other professors in the year of their promotion (see Table 5). We do not control for the length of time in the lower ranks, so we cannot tell if this is a contributing cause to the differential. However the difference is large considering the relative uniformity of all the other disciplines, so the higher salaries observed for business professors at promotion may be due to other factors than time in previous ranks.

Although there appear to be distinct patterns by discipline, these patterns may be explained in part by the number of authors for each publication (see Table 6). Hence, some disciplines, such as the humanities 
concentrated on single- or double-authored books, the health and STEM disciplines had more articles, but with many authors, on average.

\section{Publications and Salary at Time of Promotion by Discipline and Gender}

In order to examine the gender gap at promotion, we calculated the average number of promotions and salary at time of promotion by gender and the difference between genders (See Tables 7-9).

From these data it appears that, while there is a large gender gap in academic promotions, it is not explained by women having to publish more than men in order to be promoted. In about half the disciplines, men publish more articles and women publish more books, as was found in the overall gender gap before adjusting for disciplines. However, in the male-dominated disciplines of STEM and Business, men have published more of both books and articles. Therefore we must look to other explanations of the gender gap in promotions to full professor. With respect to salary, women are paid less in the year of promotion than men, except for the disciplines of education and fine arts. These differences are, however, not large (less than 5\%) and could be explained but differences in length of time in the previous rank. In other words, these small differences might be due to women being promoted earlier than their male counterparts, however other factors such as initial salary at the time of hiring might also be present.

\section{Discussion}

This paper investigates gender inequality among academics with a focus on the promotion process to full professor. Previous research has established the existence of a gender gap in the pay of Ontario academics; the promotion process has been identified as a potential mechanism for this gender wage gap. This project examined 933 professors promoted to the rank of full professor in Ontario in the period 2010-2014 using publicly available information on professor salaries and publications. Although we find very large gender gap in promotion to full professor in Ontario, differences in the number of publication by gender do not explain this gap. Instead the gender gap in promotions was explained by differences in academic discipline, number of authors per publication and publication type, all of which contribute to the gender gap in academic promotions. For example, promotions in the male dominated disciplines of business and STEM are highly over-represented and lead to overrepresentation of men in promotions. Conversely, female-dominated 
disciplines such as the humanities are smaller in comparison, leading to fewer promotions to women than to men. Moreover, the number of authors per publication is radically different by academic discipline as are the types of publications.

\section{Alternate Explanations}

The sizes of the various departments and disciplines within universities may be a result of the balancing of a number of priorities at both the institutional and governmental levels. A key consideration is planning for the instruction of the anticipated numbers of students. For example, the enrollment in university programs for such professions as medicine, law and education may be affected by the perceived need for these roles by government planners who base their predictions on demographic estimates. In this way, enrollment in these programs may be limited (or increased) directly and indirectly by government policy. These professions did not exhibit a marked gender imbalance in our data and so this component of the teaching load is an unlikely explanation for our results. Another consideration, at both the institutional and governmental level is the number of students expected to choose a given discipline.

As student enrollment and preferences vary over time, universities try to balance their course offerings and teaching loads so that an adequate complement of teachers is available to handle expected demand. To explore this possible explanation for our findings, consider the Ontario university enrollments by discipline shown in Figure 4.

Enrollment patterns in Ontario show steady growth in Health, Business and Social Science programs. Hence the greater number of male promotions in Business and Social Science may be explained, at least in part, by steadily growing enrollments. STEM enrollments are proportionately flat or decreasing and, the largest component of these, Engineering, remains highly male dominated (see Table 10). The dramatic flight of students from the Humanities might portend fewer promotions for women and a growing gender gap in faculty as a potential consequence of declining enrollment, particularly male enrollment. The massive over-representation of mainly male STEM promotions however is not explained by enrollments, so we must look outside of teachingrelated factors.

The largest component of the gender gap in academic promotions to full professor is the STEM disciplines. Of these, the greatest proportion of the gender gap, by far, was accounted for by Engineering (about half the STEM gender gap by itself). Thus, the gender gap in promotions 
observed in this study could be a consequence of a policy emphasis on traditionally male-dominated academic disciplines (STEM and especially engineering) over those traditionally dominated by women. Hence, emphasis on STEM fields ultimately appears to correspond to a funding pattern that, proportionally, disadvantages female academics. But another possibility involves shifting patterns of research funding and its control.

There are trends in research funding that differentially affect research by gender and could be relevant in, at least partially, explaining the gender gap in academic promotions. The first is a shift of policy-related research to directed research conducted by, or under the control of, internal government departments, away from universities. This enables the government to quietly explore policy questions according to a topdown agenda and provides greater control over the information that is released to the public. Although this may raise the total amount spent on social science research, it increases control over both the research topic and the dissemination of the results, which may be the main motivation for the growth of this form of research. It also has effects on the content of the research and those who perform it. Hence the research is generally top-down, applied research, rather than novel and independent. This movement of social science research under the wing of government may impact the need for social science researchers in the academy and consequently opportunities for women as faculty.

The second trend is a shift in the emphasis of research from basic science to applied sciences, such as engineering, which are more practical and have a greater commercial potential (at least in the shorter term). This shift in emphasis has the potential of reducing the direct cost to taxpayers of the university, while moving the cost of this research from its traditional domain (research and development in for-profit businesses) to publicly supported universities. In other words, businesses can externalize some of their research and development costs and the university has a greater possibility of gaining a source of revenue (from patents, for example), which the government could use to reduce public funding, albeit at a cost to more fundamental, less directly practical, research. A similar pattern involves grants available from funding agencies. These funds are becoming more directed over time. That is, government interests rather than those proposed by researchers direct the topic of research: a topdown instead of bottom-up approach. Hence the move to traditionally male-dominated professions might also be explained by an attempt to benefit businesses, increase political control and reduce taxes. Both of these trends signal an emphasis of applied and directed research over 
more independent and fundamental inquiry, which could tend to reduce the female and increase the male complement of the professoriate.

\section{LIMITATIONS}

These results have many limitations and should be considered in their context. We do not adjust for some important variables such as the quality and impact of publications, grants, patents or other factors important for promotion other than the number of peer-reviewed articles, academic books, edited books and book chapters. Although these are usually considered in promotion decisions, they are only some of the factors that weigh on this decision. Some disciplines, such as fine arts do not even use the number of publications as one of the main criterion, using instead other criteria such as performances or exhibits. Further we do not adjust for many things such as the number of people with the potential for promotion (associate professors), the time in previous ranks, family status or time taken for maternity leave, all of which may have some explanatory power. Moreover, other factors such as gender bias in access to scientific equipment, article acceptance, awards of such things as Canada Research Chairs, and other systemic barriers, we leave to future researchers.

Despite these limitations, this project provides evidence that there is a gender gap in academic promotions and points to further research that may more completely explain the reasons for it.

\section{Conclusions}

This study finds a large, and likely widening, gender gap in promotions of academics to full professor. We find that the gap is best explained by structural differences in gendered academic disciplines. In other words, the STEM disciplines, and especially engineering, which are predominantly male, have more authors per publication and emphasize journal articles over books. In our data, men tended to publish more articles up to their year of promotion than women, whereas women tended to publish more books. Student enrollment trends in STEM disciplines does not explain this structural difference; we speculate that the emphasis on STEM might be related in part to an interest in control over research by governments and policies that seek short-term results and reduced costs for business. When the number of authors per publication are accounted for, the differences between disciplines are much smaller than the gross publication counts would indicate. Perhaps 
the equivalent articles or books (i.e. discounted by the number of authors) could be a useful metric, especially in comparisons between disciplines. Business professors earn considerably more in their year of promotion than do professors in other disciplines. Student enrollment decreases in the humanities represent a threat to gender equity since this is a femaledominated discipline and the teaching complement may be affected by lack of student enrollment.

\section{REFERENCES}

Barbezat, D. A., \& Hughes, J. W. (2005). Salary structure effects and the gender pay gap in academia. Research in Higher Education, 46(6), 621-640.

Barrios, M., Villarroya, A., \& Borrego, Á. (2013). Scientific production in psychology: A gender analysis. Scientometrics, 95(1), 15-23.

Benjamin, E. (1999). Disparities in the salaries and appointments of academic women and men. Academe, 60-62.

Bentley, J.T., \& Adamson, R. (2003). Gender differences in the careers of academic scientists and engineers: A literature review. Division of Science Resource Statistics, National Science Foundation. Retrieved from https://files.eric.ed.gov/fulltext/ED478916.pdf

Blackaby, D., Booth, A. L., \& Frank, J. (2005). Outside Offers and the Gender Pay Gap: Empirical Evidence from the UK Academic Labour Market. The Economic Journal, 115(501), F81-F107.

Bordons, M., Morillo, F., Fernández, \& Gómez, I. (2003). One step furhter in the production of bibliometric indicators at the micro level: Differences by gender and professional category of scientists. Scientometrics, 57(2). 159-173.

Brown, L. (2012, Mar 24). Top-paid university profs are in business (naturally). Toronto Star, p. GT.4.

Brown, L. K., Troutt, E., \& Prentice, S. (2011). Ten years after: Sex and salaries at a Canadian university. Canadian Public Policy, 37(2), 239-255.

Carter, T.E., Smith, T.E., \& Osteen, P.J. (2017). Gender comparisons of social work faculty using H-Index scores. Scientometrics, 111(3). 1547-1557.

CAUT. (2011). Understanding male-female salary differentials amongst Canadian academic staff. CAUT Equity Review, 1(5), 1-8.

Cole, J.R., \& Zuckerman, H. (1984). The productivity puzzle: Persistance and change in patterns of publication of men and women scientists. In P. Maehr \& M. W. Steinkemp (Eds.), Advances in motivation and achievement. Greenwich, Conneticut, USA: JAI Press.

Comm,C.L., \& Mathaisel,D.F.X.(2003).Acase study of the implications of faculty workload and compensation for improving academic quality. International 
Journal of Educational Management, 17(5), 200-210. Retrieved from https://www.emeraldinsight.com/doi/abs/10.1108/09513540310484922. doi:doi:10.1108/09513540310484922

Dulek, R. E., \& Fielden., J. S. (1992). Why fight the system? The non-choice facing beleaguered business faculties. Business Horizons( Sept.-Oct.), 13-19.

Hunter, L., \& Leahey, E. (2010). Parenting and research productivity: New evidence and methods. Social Studies of Science.

Jung, J. (2012). Faculty research productivity in Hong Kong across academic discipline. Higher education studies, 2(4), 1-13.

Kyvik, S. (2003). Changing trends in publishing behaviour among university faculty, 1980-2000. Scientometrics, 58(1). 35-48

Larivière, V., Vignola-Gagné, E., Villeneuve, C., Gélinas, P., \& Gingras, Y. (2011). Sex differences in research funding, productivity and impact: An analysis of Québec university professors. Scientometrics, 87(3), 483-498.

Long, J. S. (1992). Measures of sex differences in scientific productivity. Social Forces, 71(1), 159-178.

Mauleón, E., Bordons, M., \& Oppenheimer, C. (2008). The effect of gender on research staff success in life sciences in the Spanish National Research Council. Research Evaluation, 17(3). 213-225.

McMaster University Office of Institutional Research and Analysis. (2014). Summary of an Analysis of Gender Pay Equity of Full-Time Faculty Members. Retrieved from http://www.mcmaster.ca/vpacademic/ documents/Gender_Pay_Equity_Analysis_Final_Summary Mar 31 2014.pdf

Nakhaie, M. R. (2002). Gender differences in publication among university professors in Canada. Canadian Review of Sociology/Revue canadienne de sociologie, 39(2), 151-179.

Ornstein, M., \& Stewart, P. (1996). Gender and faculty pay in Canada. Canadian Journal of Sociology/Cahiers Canadiens de Sociologie, 461-481.

Prpić, K. (2002). Gender and productivity differentials in science. Scientometrics, 55(1). 27-58.

Sen, A., Ariizumi, H., \& Desousa, N. (2014). Evaluative the relationship between pay and research productivity: Panel data evidence from Ontario universities. Canadian Public Policy, 40(1), 1-14.

Shin, J. C., \& Cummings, W. K. (2010). Multi-level analysis of academic publishing across discipline: Research performance, collaboration, and time on research. Scientometrics, 85(2), 582-594.

Statistics Canada. (2009). Salaries and Salary Scales of Full-time Teaching Staff at Canadian Universities, 2008/2009: Preliminary Report. Retrieved from Ottawa: 
Statistics Canada. (2012). Salaries and Salary Scales of Full-time Teaching Staff at Canadian Universities, 2010/2011: Final Report. Retrieved from Ottawa:

Statistics Canada. (2017). Table 477-0017 Number of full-time teaching staff at Canadian universities, by rank, sex, Canada and Provinces, *Archived*. Retrieved from http://www5.statcan.gc.ca/cansim/a26?lang=eng\&retrLa $\underline{n g}=$ eng\&id $=4770017 \&$ tabMode $=$ dataTable $\& \operatorname{srchLan}=-1 \& p 1=-1 \& p 2=9$

van Arensbergen, P., van der Weijden, I., \& van den Besselaar, P. (2012). Gender differences in scientific productivity: A persisting phenomenon? Scientometrics, 93(3). 857-868.

Warman, C., Woolley, F., \& Worswick, C. (2010). The evolution of male-female earnings differentials in Canadian universities, 1970-2001. Canadian Journal of Economics/Revue canadienne d'économique, 43(1), 347-372.

Xie, Y., \& Shauman, K. A. (1998). Sex differences in research productivity: New evidence about an old puzzle. American Sociological Review, 847-870.

\section{Figures, Tables, ANd Appendices}

\section{Figure 1}

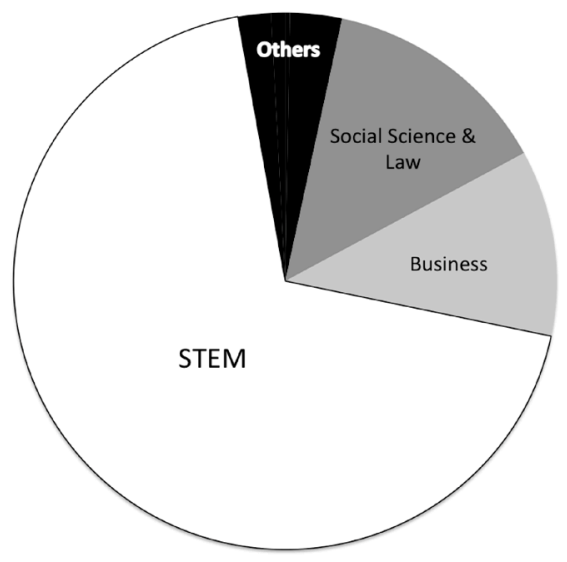


Figure 2
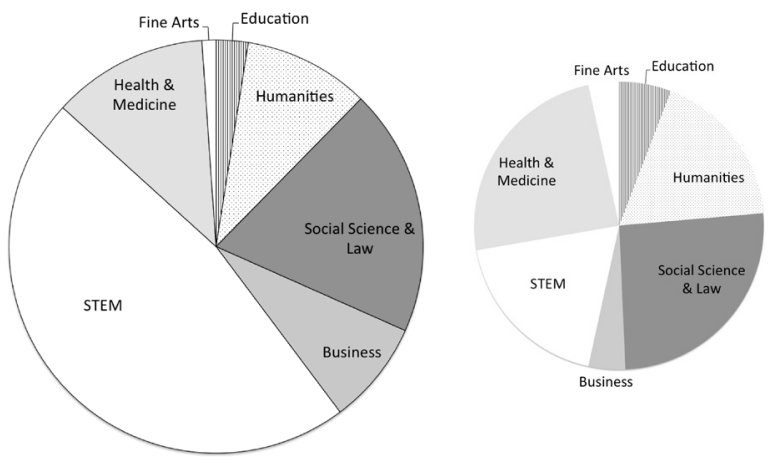

Figure 3
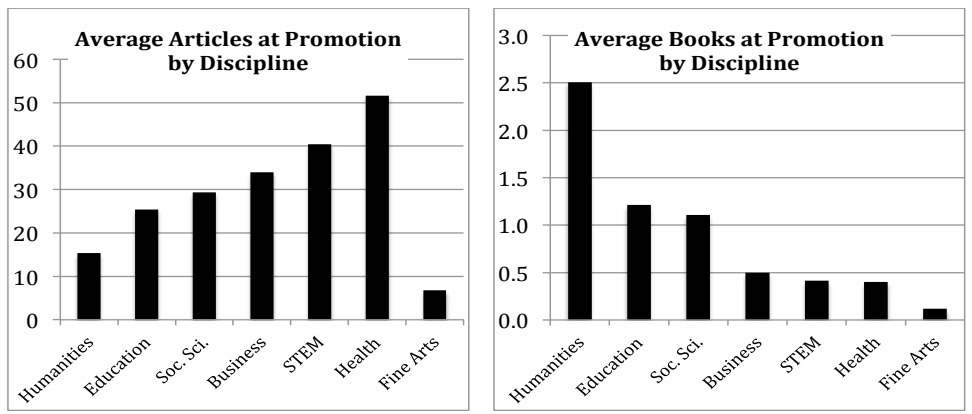

Figure 4

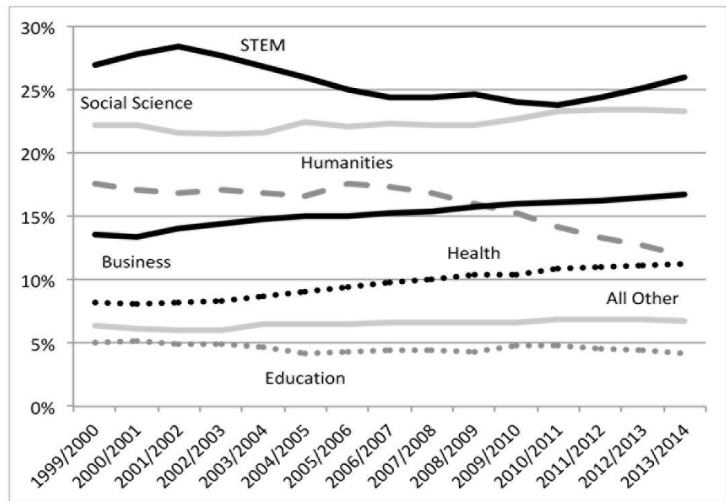

Figure 1: University Enrollments by Program and Academic Year

Source: CANSIM table 477-0029, ON University Students in Degree programs 
Table 1: 10th Percentile of Academic Full Professor Salary

\begin{tabular}{|c|c|c|}
\hline & $\underline{2008 / 2009}$ & $\underline{2010 / 2011}$ \\
\hline Brock & $\$ 117,442$ & $\$ 130,165$ \\
\hline Guelph & $\$ 118,821$ & $\$ 132,326$ \\
\hline Laurentian & & $\$ 129,260$ \\
\hline McMaster & $\$ 119,347$ & $\$ 131,807$ \\
\hline Ottawa & $\$ 110,740$ & $\$ 124,148$ \\
\hline Queen's & & $\$ 106,747$ \\
\hline Ryerson & & $\$ 131,432$ \\
\hline Trent & $\$ 127,854$ & $\$ 136,723$ \\
\hline Waterloo & $\$ 124,780$ & $\$ 130,721$ \\
\hline Western & & $\$ 111,508$ \\
\hline Windsor & & $\$ 122,926$ \\
\hline York & $\$ 96,670^{*}$ & $\$ 131,087$ \\
\hline
\end{tabular}

Source: University and College Academic Staff Survey (UCASS)

* Faculty at York were on strike for 85 days of this period

Table 2: Universities by Type

Primarily Undergraduate

Lakehead

Laurentian

Nipissing

Trent

UOIT
Comprehensive

Brock
Guelph
Ryerson
Waterloo
Windsor

York
Medical/Doctoral

McMaster

Ottawa

Queen's

Western 
Table 3: Promotions by Discipline and Gender

\begin{tabular}{|c|c|c|c|c|c|c|c|}
\hline \multirow[b]{2}{*}{ Discipline } & \multicolumn{2}{|c|}{ Women } & \multicolumn{2}{|c|}{ Men } & \multicolumn{2}{|c|}{ Gender Gap* } & \multirow{2}{*}{$\frac{\text { Tota }}{\underline{\mathbf{l}}}$} \\
\hline & $\underline{\mathbf{N}}$ & Pct. & $\underline{\mathbf{N}}$ & Pct. & $\underline{\mathbf{N}}$ & Pct. & \\
\hline Business & 12 & $4 \%$ & 52 & $8 \%$ & $(40)$ & $11 \%$ & 64 \\
\hline Education & 17 & $6 \%$ & 16 & $2 \%$ & 1 & $0 \%$ & 33 \\
\hline Engineering** & 18 & $6 \%$ & 139 & $22 \%$ & (121) & $35 \%$ & 157 \\
\hline Fine Arts & 10 & $3 \%$ & 7 & $1 \%$ & 3 & $-1 \%$ & 17 \\
\hline Health & 34 & $12 \%$ & 30 & $5 \%$ & 4 & $-1 \%$ & 64 \\
\hline Humanities & 52 & $18 \%$ & 63 & $10 \%$ & (11) & $3 \%$ & 115 \\
\hline Law & 9 & $3 \%$ & 13 & $2 \%$ & (4) & $1 \%$ & 22 \\
\hline Math-Comp & 10 & $3 \%$ & 69 & $11 \%$ & $(59)$ & $17 \%$ & 79 \\
\hline Medicine & 37 & $13 \%$ & 48 & $7 \%$ & (11) & $3 \%$ & 85 \\
\hline Science & 27 & $9 \%$ & 93 & $15 \%$ & (66) & $19 \%$ & 120 \\
\hline Social Science & 66 & $23 \%$ & 111 & $17 \%$ & $(45)$ & $13 \%$ & 177 \\
\hline Total & 292 & $31 \%$ & 641 & $69 \%$ & (349) & $100 \%$ & 933 \\
\hline
\end{tabular}

Table 4: Average Publications and Salary by Discipline

\begin{tabular}{|c|c|c|c|c|c|}
\hline Discipline & $\begin{array}{l}\text { Journal } \\
\text { Articles }\end{array}$ & $\underline{\text { Books }}$ & $\begin{array}{l}\text { Edited } \\
\text { Books } \\
\end{array}$ & $\begin{array}{c}\text { Book } \\
\text { Chapters } \\
\end{array}$ & Salary* \\
\hline$\overline{\text { Humanities }}$ & 15.3 & 2.5 & 0.5 & 3.5 & $\$ \overline{\$ 131,347}$ \\
\hline Education & 25.4 & 1.2 & 0.2 & 4.7 & $\$ 130,245$ \\
\hline Social Science & 29.3 & 1.1 & 0.4 & 3.1 & $\$ 140,009$ \\
\hline Business & 33.9 & 0.5 & 0.1 & 3.2 & $\$ 186,904$ \\
\hline STEM & 40.4 & 0.4 & 0.1 & 2.8 & $\$ 138,918$ \\
\hline Health & 51.6 & 0.4 & 0.1 & 0.8 & $\$ 142,110$ \\
\hline Fine Arts & 6.8 & 0.1 & 0.4 & 1.2 & $\$ 130,495$ \\
\hline Total & 35.2 & 0.8 & 0.2 & 2.7 & $\$ 141,559$ \\
\hline
\end{tabular}


Table 5: Publications by Discipline, Adjusted for the Number of Authors

\begin{tabular}{|c|c|c|c|c|}
\hline Discipline & $\begin{array}{l}\text { Journal } \\
\text { Articles } \\
\end{array}$ & Books & $\begin{array}{l}\text { Edited } \\
\text { Books }\end{array}$ & $\begin{array}{c}\text { Book } \\
\text { Chapters }\end{array}$ \\
\hline$\overline{\text { Humanities }}$ & 11.5 & 2.1 & 0.4 & 3.2 \\
\hline Education & 15.2 & 0.8 & 0.2 & 2.4 \\
\hline Social Science & 13.9 & 0.7 & 0.2 & 2.2 \\
\hline Business & 15.7 & 0.3 & 0.0 & 1.7 \\
\hline STEM & 13.8 & 0.2 & 0.0 & 1.1 \\
\hline Health & 15.7 & 0.2 & 0.0 & 0.5 \\
\hline Fine Arts & 4.4 & 0.1 & 0.2 & 1.0 \\
\hline Total & 13.8 & 0.6 & 0.1 & 1.6 \\
\hline
\end{tabular}

Table 6: Overall Average Publications by Gender

\begin{tabular}{|c|c|c|c|c|c|c|}
\hline Gender & $\begin{array}{l}\text { Journal } \\
\text { Articles } \\
\end{array}$ & Books & $\begin{array}{l}\text { Edited } \\
\text { Books }\end{array}$ & $\begin{array}{c}\text { Book } \\
\text { Chapters } \\
\end{array}$ & Salary* & $\underline{\mathrm{N}}$ \\
\hline$\overline{\text { Female }}$ & 29.1 & $\overline{1.1}$ & 0.2 & 2.6 & $\$ 138,646$ & $2 \overline{9} 2$ \\
\hline Male & 38.0 & 0.7 & 0.2 & 2.7 & $\$ 142,885$ & 641 \\
\hline $\begin{array}{l}\text { Total } \\
\text { * includ }\end{array}$ & $\begin{array}{c}35.2 \\
\text { benefits }\end{array}$ & 0.8 & 0.2 & 2.7 & $\$ 141,559$ & 933 \\
\hline
\end{tabular}

Table 7: Average Publications by Discipline for Women

\begin{tabular}{|c|c|c|c|c|c|}
\hline Discipline & $\begin{array}{l}\text { Journal } \\
\text { Articles } \\
\end{array}$ & Books & $\begin{array}{l}\text { Edited } \\
\text { Books }\end{array}$ & $\begin{array}{c}\text { Book } \\
\text { Chapters } \\
\end{array}$ & Salary \\
\hline$\overline{\text { Education }}$ & 19.8 & $\overline{1.5}$ & $\overline{0.2}$ & 3.6 & $\$ \longdiv { 1 3 2 , 6 4 6 }$ \\
\hline Humanities & 14.0 & 2.9 & 0.5 & 4.3 & $\$ 131,060$ \\
\hline \multicolumn{6}{|l|}{ Social Science \& } \\
\hline Law & 23.9 & 1.0 & 0.3 & 2.5 & $\$ 138,793$ \\
\hline Business & 32.3 & 0.2 & 0.0 & 3.4 & $\$ 184,113$ \\
\hline STEM & 38.4 & 0.2 & 0.1 & 2.4 & $\$ 134,888$ \\
\hline Health \& Medicine & 42.7 & 0.6 & 0.0 & 1.2 & $\$ 141,468$ \\
\hline Fine Arts & 9.8 & 0.2 & 0.7 & 2.0 & $\$ 133,266$ \\
\hline Total & 29.1 & 1.1 & 0.2 & 2.6 & $\$ 138,646$ \\
\hline
\end{tabular}




\begin{tabular}{|c|c|c|c|c|c|}
\hline Discipline & $\begin{array}{l}\text { Journal } \\
\text { Articles } \\
\end{array}$ & Books & $\begin{array}{l}\text { Edited } \\
\text { Books } \\
\end{array}$ & $\begin{array}{c}\text { Book } \\
\text { Chapters }\end{array}$ & $\underline{\text { Salary }}$ \\
\hline Education & 31.4 & 0.9 & 0.3 & 5.8 & $\$ 127,693$ \\
\hline Humanities & 16.5 & 2.2 & 0.6 & 2.8 & $\$ 131,584$ \\
\hline Social Science \& & & & & & \\
\hline Law & 32.6 & 1.2 & 0.4 & 3.5 & $\$ 140,744$ \\
\hline Business & 34.3 & 0.6 & 0.1 & 3.1 & $\$ 187,548$ \\
\hline STEM & 40.8 & 0.4 & 0.1 & 2.8 & $\$ 139,654$ \\
\hline Health \& Medicine & 59.8 & 0.2 & 0.1 & 0.5 & $\$ 142,695$ \\
\hline Fine Arts & 2.6 & 0.0 & 0.0 & 0.0 & $\$ 126,535$ \\
\hline Total & 38.0 & 0.7 & 0.2 & 2.7 & $\$ 142,885$ \\
\hline
\end{tabular}

Table 9: Gender Gap* in Average Publications by Discipline (negative values indicate higher values for women

\begin{tabular}{|c|c|c|c|c|c|}
\hline Discipline & $\begin{array}{c}\text { Journal } \\
\text { Articles }\end{array}$ & Books & $\begin{array}{l}\text { Edited } \\
\text { Books }\end{array}$ & $\begin{array}{c}\text { Book } \\
\text { Chapters }\end{array}$ & Salary \\
\hline$\overline{\text { Education }}$ & 11.7 & $\overline{(0.5)}$ & $\overline{0.1}$ & 2.2 & $\$ \$ 4,953$ \\
\hline Humanities & 2.5 & $(0.7)$ & 0.1 & $(1.5)$ & $(\$ 524)$ \\
\hline Social Science \& & & & & & \\
\hline Law & 8.7 & 0.2 & 0.1 & 0.9 & $(\$ 1,952)$ \\
\hline Business & 2.1 & 0.4 & 0.1 & $(0.3)$ & $(\$ 3,435)$ \\
\hline STEM & 2.5 & 0.2 & 0.0 & 0.5 & $(\$ 4,766)$ \\
\hline Health \& Medicine & 17.1 & $(0.4)$ & 0.0 & $(0.6)$ & $(\$ 1,227)$ \\
\hline Fine Arts & $(7.2)$ & $(0.2)$ & $(0.7)$ & $(2.0)$ & $\$ 6,731$ \\
\hline Total & 8.9 & $(0.3)$ & $(0.0)$ & 0.2 & $(\$ 4,239)$ \\
\hline
\end{tabular}

* Negative numbers mean women publish more or are paid less.

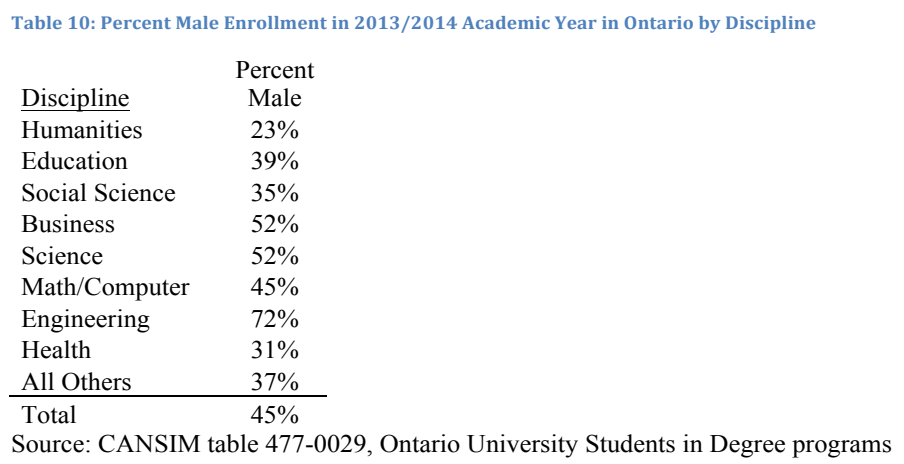


Paul Millar is Associate Professor in the School of Criminology and Criminal Justice at Nipissing University where he pursues a variety of research interests.

Email: paulmi@nipissingu.ca

Jane Barker is an Associate Professor in the School of Criminology and Criminal Justice at Nipissing University. Her research interests include Women and the Criminal Justice System, Mental Health, Corrections and Policing. 
70 (c) Canadian Journal of Sociology/Cahiers canadiens de sociologie 45(1) 2020 